\title{
A Few More Words about Beowulf
}

\author{
Translated and Annotated
}

\author{
Mark Bradshaw Busbee
}

In September of 1815, Grundtvig published his second article about Beowulf, "Nok et Par Ord om Bjovulfs Drape" [A Few More Words about the Heroic Poem of Beowulf] in Nyeste Skilderie af Kjøbenhavn [The Latest Scenes of

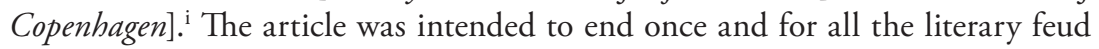
that had developed between him, Grímur Jónson Thorkelin, who had published the first modern edition of Beowulf, and Peter Erasmus Müller, who had anonymously reviewed the edition. ${ }^{\text {ii }}$ The article is notable for two main reasons: first, it reveals Grundtvig far ahead of his contemporaries as a scholar of the poem and, second, it displays in full Grundtvig's aggressive tone when in the heat of debate.

\section{Introduction}

In the summer of 1815, Grundtvig wrote "Et Par Ord om det nys udkomne angelsaxsiske Digt" [A Few Words about the Recently Published Anglo-Saxon Poem]. ${ }^{\text {iii }}$ In it, he scolded Müller for blindly following the Latin paraphrase that Thorkelin provided in his edition. Along the way he indirectly suggested that Thorkelin was guilty of making crucial mistakes that revealed fundamental misunderstandings of the poem's contents. On 22 and 26 August with "Svar til: 'Et Par Ord”" (Answer to: 'A Few Words'), Thorkelin defended his edition (and himself) by ridiculing Grundtvig's approach in "Et Par Ord" and refuting some of his arguments. iv Grundtvig sent Thorkelin an apology letter, dated August 28, but the following day, possibly before the letter arrived at its destination, a brief, scathing 
critique of Grundtvig's ideas about Beowulf appeared in the Danske Litteratur-Tidende [Danish Literary Times].

The piece, thought to have been written by Müller, claimed that Grundtvig's wild theories and poetic thinking often led him down too many wild paths, that his incorrect translation of portions of Beowulf in the first part of "Et Par Ord" was evidence of his untamed mind, and that he was in no position to critique Thorkelin's work so harshly (Müller 1815, no. 29, 461-2). These comments, combined with Thorkelin's statements in "Svar til: 'Et Par Ord'," inspired Grundtvig to directly attack Thorkelin in "Nok et Par Ord." The article reveals the manner in which Grundtvig addressed fellow scholars in Copenhagen at that time; it sometimes matches Thorkelin's sarcastic tone in "Svar til: 'Et Par Ord"; at other times it expresses what might be called a tone of "surprised insouciance of first Müller's, and then Thorkelin's response” (Bradley 2000, 37). It carefully addresses Thorkelin's points one-by-one, using grammar (George Hickes' 1705 Thesaurus) and Dictionary (William Somner's 1659 Dictionarium Saxonico-Latino-Anglicum) as "proof."vi

The article reveals the sophistication with which Grundtvig understood the contents and workings of Beowulf; it even includes consideration of how Thorkelin might have gone wrong in his Latin paraphrase of key passages, such as the first 52 lines. Historical distance allows us to enjoy the audacity of Grundtvig's remarks and admire his erudition, particularly his employment of a combination of comprehensive knowledge of Norse legend and history, disciplined use of Hickes' Thesaurus and Somner's Dictionary (which he personifies as married giant folk) and, often conspiciously, his imagination. The article seems to have effectively ended the literary feud: a week after the last part of "Nok et Par" appeared, Johan Bülow, a patron of both Thorkelin and Grundtvig, commissioned Grundtvig to write a Danish translation of Beowulf, $f^{\mathrm{vii}}$ and on 24 October Børge Pontoppidan, the editor of Nyeste Skilderie, published an open letter defending Grundtvig and calling an end to the feud. ${ }^{\text {viii }}$

"Nok et Par Ord" has not been previously translated in its entirety into English. In what follows, an attempt has been made to accurately render Grundtvig's style, which is highly allusive and makes use of circuitous and idiomatic phrasing, while staying true to his tone and making his points about the poem as clear as possible. Grundtvig often refers to pages in Thorkelin's edition of Beowulf. This practice is complemented by provid- 
ing in brackets the corresponding line numbers in the edition of Beowulf by Fulk, Bjork and Niles (2009). The translation also maintains Grundtvig's practices of using italics for emphasis and small capital letters to set apart Old English text. The source-text is the edition of "Nok et Par Ord," created by Vibeke Arendse Pedersen for Grundtvigs-Værker (grundtvigsvaerker.dk). Pedersen was of tremendous assistance, especially in explaining many of Grundtvig's allusions. Thanks also go to Edward Broadbridge and S.A.J. Bradley, both accomplished translators of Grundtvig's work, for their suggestions and advice, and to Professor Steven R. Todd of Samford University for his advice on how best to render Thorkelin's Latin paraphrases in graceful English.

\section{A Few More Words about the Heroic Poem Beowulf}

No. 70, Cols. 1105-1109 As was to be expected, the publisher of this poem, State Counselor Thorkelin, has taken my previous few words very badly, and, even though it was not my intention to tell him things that he found hard to endure, I would not particularly blame him for this. I could possibly object a little more to him speaking to me as a teacher would to a schoolboy who must sit up and listen, but, as things are now, this is the fashion in the Danish publishing world, and fashion, as one knows, is a tyrant whose friends suffer so much that one must not be too severe in this respect. However, the publisher has become so overexcited that he declares all of my corrections to be nonsense and madness, and he stubbornly claims that I cannot possibly prove them. This is overdone, and in this case I must not be silent, especially when the publisher himself will not admit that he has crossed the line. Since he will not do so, and no matter how unwilling I am to take advantage of the old man's weakness, I am forced to make sure that I erase the schoolboy label he has stamped on my remarks in A "Few Words". However cruel it may seem to disturb the schadenfreude that [Thorkelin's] critique has doubtless aroused in many people, I cannot actually say that I have a guilty conscience in doing this, since it is not $m y$ fault that they believe me to be not only poor but also incompetent, to blame me unjustly for what I did not understand in order to give my enemies a triumph, and to supply me with a skillful chastisement of Grammar and Dictionary; these are two reliable, unbi- 
ased married people, and whoever they get their claws into will be saved neither by prayers nor by flight. I am now obliged to let the publisher fall into such hands, even though it is not my fault that he has provoked the two giants [i.e. Grammar and Dictionary], and all that I can do now is to avoid inflicting any harm, and to point out to him the position in which he has placed himself. If Grammar and Dictionary acquit him, then I have nothing against it, but they will acquit me first, for like a child I have taken each step in their care ${ }^{1}$ - and now to the subject at hand.

I have stated that the publisher has confused several events and transformed the names of the princes Hrēðel, Herebeald, Hæðcyn and Heardrēd into insignificant adjectives. Assuming, as I have shown, that these words occur more frequently and in completely remarkable groupings, there can be no question that they are male names, since it can only create major confusion to translate them as adjectives. The publisher would surely not deny this, but he does deny with confidence the main assumption, as I shall now demonstrate. It is clear that here the question is not whether these words could be used as adjectives, nor whether they perhaps could be used that way elsewhere-for any name that has any significance in the language could be used that way, and so might Hrōðgār and Hrōomund; here the question is only whether they are used as adjectives in Bjovulfs Drape. First let me say that we never find any of those words in the poem applied to a name, which is otherwise | Col. 1107 customary; second, that four people are immediately detectable in the poem who do not have names other than these words; and that these words are never used except in reference to these four. If my assertion is not irrefutably proven when I have finished, then I do not know what it means "to prove."

Hrēðel. ${ }^{2}$ This word first appears on p. 31 [373-75], where Hrōðgār says that the Goths' Hrēðel gave his only daughter to Beowulf's father Ecgpēow, and here in my view it is already clearly a name. It most certainly cannot be an adjective because there is no word for it to modify, unless it is a common

1 In this sentence Grundtvig uses the Danish term ledebaand, which refers to a device like reins that parents used at the time to hold children upright as they learn to walk.

2 Hrēðel is a king in the Geatish royal line, the maternal grandfather of the protagonist Beowulf, and the father of Beowulf's uncle and king, Hygelāc. 
or special royal name. Here we will set aside the question of what kind of name it is and note only that the king of the Goths who is spoken about in these lines cannot be Hyġelāc because he was young in Beowulf's manhood and could therefore not be Beowulf's maternal grandfather. ${ }^{3} \mathrm{On}$ the other hand, we see clearly from the timeline that the king could well be Hygelāc's father. On p. 113, 139, 176 and 222 [1485, 1847, 2358, and 2992], Hyġelāc is called precisely Hrēðel's son (sunu, EAFERAN HREbles [the son of, the offspring of Hrēðel]) and again on p. 144 [1923] he is called HYĠELĀC HRÉPLINGEN, a word which surely is just as much derived from a name as is Skefing, Skylding, etc. From this I believe it to be as clear as daylight that Hrēðel is the name of Hygeläc's father. Finally, on p. 181 [2428-31], Beowulf says that King Hrèdel (HREpel cyning) took him to his father's house as a seven-year old boy and raised him, and, on p. 184 [2472-74] he says that after Hrēðel died, the war between the Swedes and the Goths began. Once we have added to this p. 164 [2191] where rather unclearly — at least to me-it says Hrēðel's heirloom, the word is no longer to be found in the poem, ${ }^{4}$ though HRÈPLING is used again on pp. 217 and 219 [2925 and 2960] to refer to Hygelāc and his brothers. Since Hrēðel is so obviously a name, it is no wonder that it has caused great embarrassment to the publisher who failed to acknowledge it, a point that also shows itself in the fact that he translates it, depending on circumstances, as: Rex, Princeps, celer, timore vacuus, verendus, pectus [king, prince, swift, fearless, respectable, heart (or mind)].

Herebeald and Hæðcyn. ${ }^{5}$ These words do not appear in the poem before p.181 [line 2425], where Beowulf says that the greatest setback Hrēðel had was with his children, Herebeald and Hæðcyn and Hygelāc. The publisher says that nothing was worse for him (meaning Hygielāc, in the publisher's opinion) than the | Col. 1108 powerfully-armed heathens

3 Likely with an eye to contemporary international politics, Grundtvig prefers the designation "Goth" to the name "Gंeat" in Beowulf to suggest that the Goths were long-time allies of the Danes and enemies of the Swedes.

4 Grundtvig is referring here to the phrase "Hrēðeles lāfe" at line 2191, which can be translated as "the leavings of Hrēðel" and refers to a famed sword Hrēðel left as an heirloom.

5 Herebeald and Hæðcyn are, respectively, the oldest and second oldest sons of Hrēðel. They are the older brothers of Hygelāc. 
were for his children and Hygelāc. Without pointing out that both the skald and Grammar would object to this, I will just mention the fact that Hygelāc — a clear nominative-which by a conjunction is bound to two other nominatives (HEREBEALD AND HÆrCYN), must otherwise be torn up and turned into a dative - which the grammar in no way allows. Again, even the publisher must confess that the complete narrative through pages 182, 183, and 184 [2434-43, 2462-71] speaks of a fratricide and a father's grief. On p. 182, after the words Herebeald, Нæðcyn, Hygelāc, we read the following: the eldest fell by his brother's hand since Нæðcyn shot his beloved. I think it is settled that Herebeald and Hæðcyn are the names of Hygelāc's brothers; and it is proven now that Hrēðel is the name of Hygelāc's father, which no one can therefore deny. To make this abundantly clear, I note that Herebeald is mentioned only once before, on p.184 [2434], when his father mourned Herebeald but could not hate his murderer because he loved him; that p. 185 [2482-83] reads Haðcyn King of the Goths; and that p. 217 [2925] has HRÆDLINGEN HÆĐCYN after which the word occurs no more.

Heardrēd. ${ }^{6}$ This word is unclear except on pp. 177 and 178 [2375 and 2388]. ${ }^{7}$ Here we read that when Hygelāc had fallen, they offered Beowulf the throne because they would not dare to make a child their king, yet no one can say that he lorded it over Heardrēd or aspired to the crown. He reared him in honor and love until he was older and could counsel himself, ${ }^{8}$ but when Ōhthere's sons came to Gothland to fight, Hygelāc's son Heardrēd was killed, and Ongenpēo's son withdrew to let Beowulf keep the throne. ${ }^{9}$ The publisher would prefer Heardrēd to be translated

6 Hygielāc's son, who succeeds his father to the throne.

7 These are the only two places where the name is written out in the poem.

8 After Hyġelāc's death, it is not the people but Queen Hyg்d who offers Beowulf the throne. He declines and acts as Heardrēd's guardian during the prince's youth (lines 2367-79).

9 By its phrasing this explanation is unclear as to whether or not Grundtvig understands that in the poem Ōhthere's sons, Eanmund and Eadgils, sought refuge and not strife at the court of Heardrēd. By "Ongenpēo's son," Grundtvig is referring to Onela, Ōhthere's brother, who attacks the Geats and kills Heardrēd, probably because he had given Onela's nephews, Eanmund and Eadgils, safe haven. These events are not related sequentially in the poem. (See lines 2202-06, 2379- 
by imperiosus [commanding] and consiliosus [insightful] to describe Hygelāc, ${ }^{10}$ even though his death in Friesland was narrated earlier in the poem [1203-11, later 2913-19], and even though he must make HEARDREDE, which is a clear dative, into a nominative, and even though, by his own confession, a son of Hygelāc is mentioned who is not given any other name than Heardrēd.

I therefore believe that I have substantiated one of my main complaints, a complaint that concerned an entire section of the poem, and one that, to be implemented, called for a thorough acquaintance with the poem | Col. 1109, and must almost unfailingly prove itself. For when one applies a method whereby unforced opinion and consistency enter where they were missing before, then one surely ought not to be required to give further proof to anyone. I have already provided significant, irrefutable proof to those who would take the trouble to read through the Latin translation with my "Et Par Ord" by their side. However, it is fair in our so very spiritual era for people to demand more tangible proof, and to refute, whoever can, those I have here provided!

No. 71, cols 1121-1123 Our sequence now comes to a few places where I have disapproved of [Thorkelin's Latin] translation, none of which is more notable than the place in the introduction where the publisher says that Beowulf's war party is being referred to and where I, on the other hand, contend that the skald is narrating the story of Skjold's funeral. The publisher calls this sheer madness and states confidently that the entire narrative is a foster-child of my own imagination, one in which the old skald has neither part nor parcel. So as not to offend the truth, I could accept the story as being my own; indeed, I do not know why I would deny it to be so, since it is such a beautiful and blessed speech that no skald ought to be ashamed of! But we must certainly call it quite inconceivable how it might occur to me to compose it myself and sneak it into the old

88, 2611-25). Liuzza (2013, 151-2) provides an outline of the events Grundtvig is discussing here.

10 In the manuscript at line 2202, the name appears as two words: "hea rede." As a result, on page 165 of his edition, Thorkelin mistranslated it as Et sublimi decreto [by sublime decree], leading him to believe that the entire line referred to Hygielāc's death, which had been mentioned 1,000 lines earlier in the poem. 
poem before my opponent's very eyes! I say "inconceivable" since to do so I would have to be very clever and very stupid and, at the same time, well-versed and ignorant about the old song. However, as valid as such proof would be to those who cannot or will not see it for themselves - and only a few would do so-I shall have to endeavor to find more tangible proof for it and, along the way, discover how difficult it is in such a case to satisfy those who do not know the language and will not be comfortable with | Col. 1122 internal proof, for here I am not addressing the linguistically proficient. If my critics do not find themselves committed enough to acknowledge that I am right, then it is too bad for them as well as for me. Now, let us take the opening of the Latin translation, where-after some perfectly clear words about Skjold Skefing ${ }^{11}$ and some half-clear ones about a son he should have had named Beowulf ${ }^{12}$ - we find a thoroughly incomprehensible speech by the skald which begins with the words: Ita debes cimeliorum and ends on p. 5 with Virtute mactas. ${ }^{13}$ What follows until the conclusion the publisher takes to be a speech about one of Beowulf's "war parties," but so much is sure that in the translation no name is mentioned, nor any rejection of the previous names, nor any information about where the voyage is headed, nor what the outcome will be. We have only a confusing speech about leaving home, about the cargo of one or more ships, and about the sorrow of the heroes that they did not know who would take home the spoils. Now how can such a translation be correct? Right away in the introduction, the old skald has had to have given us a fragment of a "war party" without head and neck, as if the story fell out of the skies, incomprehensible to anyone and inconsistent with what comes before or what follows, and with the marvelous intelligence

11 Grundtvig consistently adapts the name "Scyld" [4] to its Scandinavian form "Skjold."

12 In "Et Par Ord," Grundtvig denied the existence of Scyld's son, who is also named Beowulf at line 18. He vaguely acknowledges his mistake below at no. 72, column 1139 .

13 The complete Latin paraphrase: Ita debes cimeliorum / O Rex efficere / Prestantibus donis / Patribus (oblatis) tuis, / Ut juvenes / Post assuefiant / sequi duces, / Ubi bella venerint. / Populus persequitor / Laude res gestas / Æterna / Virtute mactas. [Thus you ought, $\mathrm{O}$ King, with excellent gifts of treasures offered to your fathers, make it so that the young men grow accustomed to follow after the leaders, when wars come. The people pursue deeds done with praise, adorned with eternal virtue.] 
in the end that the heroes went mournfully on war parties-which was not their custom-and that their sorrow was due to them not knowing who would take possession of the treasures that were on their ships, a sorrow that warriors are not accustomed to feeling for as long as their arms can move and they can hold a sword!

Against this I argue that after the speech about Skjold's | Col. 1123 might and generosity, a recital of fidelity follows that must belong to the warriors of a generous king, one that forms a natural transition to a short account of how Skjold's warriors, even after his death, showed him faithfulness and devotion. There is no denying that, taken like this, it is far more reasonable, and that it is quite unbelievable that a skald who shows himself to be no bungler in his art would immediately in the introduction move us into a vague speech that is neither one thing nor the other but is inconsistent not only with his main topic, but also with everything else in the poem. It is therefore quite logical that in the introduction, which undeniably begins with Skjold's honor, the skald would glorify only the memory of Hrōðgār's and the Skjoldings' ancestor. Can we then, following the skald's own words, still be in doubt which of the two explanations we should choose? My explanation must be chosen without further consideration. I venture also to claim that even if my explanation with respect to the skald and the context were inappropriate and the publisher's most reasonable in these respects, the clear words themselves force my explanation to be correct, and I shall strive to show how by going through the most important and clearest lines word by word.

Him pa Scyld gewat

To gestæp hwile. [26]

The publisher translates these lines as "when he was to set off at an appointed time," while I have rather translated them in rhyme as:

When Skjold had gone

In death to rest...

We can read in Somner's Dictionary that SCYLD means nothing more or less than shield - be it a weapon or a man - and that the poem and the dictionary reveal that GEWAT (imperfect of GEWITAN) means went away 
(like the Danish gik bort), both on any journey and on the long journey [of death]. From this it is clear that SCYLD here must mean the man Skjold, since time and movement follow; and next, if the relationship allows, these very words can be literally translated as: Shield died. Here we need not to take things so precisely, for just as To is to and two [the number] so also are STÆP and GESTÆP both step and footsteps and HWILE both stay and rest. Surely now there can be no $\mathbf{C o l} \mathbf{1 1 2 4}$ doubt that the passage says of Skjold that he died, and my translation is the only correct one. ${ }^{14}$ No one should expect an explanation from me about how the publisher arrived at his misunderstanding of the passage, but this much I will say: he has turned the clear substantive SCYLD into the imperfect form of the verb SCEOLDAN, which is at times written as SCYLDE, though normally, as here in the poem on p. $82[1067,1070]$ it is written as SCOLDE, meaning ought to or should. He also turns the clearly imperfect form GEWAT into the infinitive form gewitan. In this way one can certainly arrive at strange things!

Hi hine pa ætbæron

To brimes warope

Swæse gesipas

Swa he selfa bad

Penden wordum weold

Wine Scyldinga

Leof landfruma

Longe ahte. [29-31]

Here is the passage in my version:

So in hand took they,

The loving retainers,

The corpse of King Skjold;

To sea-shore they bore

In sorrowful swarm

That great lord so bold;

The corpse they brought out

14 "Et Par Ord" features a complete translation of the opening 52 lines of Beowulf (1815a, cols 948-51). See Busbee (2015, 10-14) for an English version. 
As he himself bade,

When words he still said

Upon his high throne,

And ruled with mildness

The lands far and wide,

So many a good day.

These lines might be literally translated thus: "Then they carried him out to the seashore, the sweet comrades, just as he asked when he had power over his words, the Skjoldungers' friend, the beloved father of the people, for many a good day." It is irrefutable, as it is certainly shown, that the poet tells how Skjold's men carried his corpse to the beach according to his command in the days of his life. My translation is therefore not "madness" as the publisher calls it, but a free expression of the old skald's undoubted meaning. What the publisher's translation is, others must judge, while I append it here with my comments: "The housecarls gathered on the shore. His | Col. 1125 loyal comrades he himself had asked to do this. While he with words ruled the Skjolding-friends, he was long the country's beloved father." HINE, the normal and clear accusative of HE, he, (see Hickes' Literature Septentrional p. 22) ${ }^{15}$ is then made into a nominative singular HINE, a servant, though the verb ÆTВÆRON [they carry to] is so obviously plural with the corresponding pronoun HI, they, clearly in front of it. Yet ÆтвґRON he translates as gathered, though the publisher himself knows that it is indubitably carry to (bear to), for he translates the same word thus on p. 41, line 22 [519]. Furthermore, the clearly related lines "as he himself asked" and "while he could speak" are divided by a full stop, and the clear nominate WINE, friend, is in each case made the object of its own object made-I have no idea why. The verb WEOLD, advised cannot here be in apposition to any other word than wORDUM, word, right next to it, which is therefore also in the dative form, the object of the verb of the sort it commonly controls, though WEALDAN is an exception; for otherwise it prefers

15 Here and at column 1144, Grundtvig refers to Hickes' paradigms for Old English nouns and verbs. 
the genitive (Hickes, p. 73). ${ }^{16}$ I need not elaborate on what Grammar and sound Truth might say about this.

Enough has now been said about this, for what I myself have published as being "doubtful" I am not obliged to defend. Although I see myself capable of doing so, I shall avoid unnecessary verbosity. Once it is clear that it is Skjold's death and burial which are being narrated in this passage, as I have now proven, then the publisher himself must admit that in the following passage they carried him out on a ship, the ship put out to sea, and the heroes mourned the fact that they did not know what became of the "cargo". ${ }^{17}$ Thus there can be no doubt about the accuracy of any of what I have published. Another thing I consider certain is that with the help of the legend about Scef, I think I have found the reason why Skjold wished to be buried this way. I shall discuss this further in time, but it does not interest me to quarrel with the publisher about it any more than I have blamed him for not taking note of such things.

No. 72, cols. 1139-1144 On all the other points I shall express myself briefly. As regards the Danish Beowulf, I will only say that I am far from crafty enough to pass over the word's presence in the introduction; indeed I have explicitly noted that it is also found there, and that, had it not been impossible for me to put it into my verse, I would simply have included it in the poem anyway in order to forgo an interpretation I well expected. I shall save the rest for another time.

The publisher calls HIORTA a "self-made" word, but I, at least, have not created it, as can be seen in Somner's Dictionary. ${ }^{18}$

The publisher says that I have blamed him in my discussion of the 3rd and 4th Songs for translating FYR with sword, but if the reader takes a look at Skilderiet No. 63, he will find something else: the publisher's three translations of the phrase HINE FYRWYT BRÆC, curiosity overcame him. This is surely not the place to quarrel about whether or not the word FYR, standing alone, could be translated as sword. I have never denied that FYR

16 Hickes' exact wording: "Verbum autem wealdan regit genitivum" [The word "wealdan" otherwise prefers the genitive] (73).

17 i.e. the body of King Skjold.

18 In "Svar til 'Et Par Ord'," Thorkelin contends that the word is cognate with "Herthe, the great Mother" (1815b, col. 1061). 
in this situation really is fire, but FYRWYT is never a beacon and, accordingly, the speech was about the ignes angari [bonfire] in the translation on $\mathrm{p}$. 20 [1985] and in the Index rerum on p. 237. I will not examine whether or not known word usage can be employed differently in poetry and prose, a practice the publisher justifies by translating the same words in one and the same poem in more or less opposite ways, a practice that he $\mid$ Col. 1140 confidently admits to having followed (Skilderiet No. 68), but I know well enough that such language or poetry did not offer any particular benefit.

The publisher does not like the fact that I have corrected the "300 men" in the 6th Song on p. 31 [379-81], which he attaches to Beowulf, to thirty man's strength. He contends that "xxxtiges" means thirty score, which then really means that it was not three but six hundred, but I would just note that whatever it was, the poem states explicitly that Beowulf had them in his grip, ON HIS MUNDGRIPE, and whether they were 300 or 600 men, it was a little too many! ${ }^{19}$

About Beowulf's weapons I will say only that the weapons, but no grave, are mentioned after the words (p. 36 [452]) "Send to Hygelāc" (ONSEnd HIG̈ELACE). The meaning surely cannot be in doubt.

In the 7th Song ("6th" is a printing error) I note the absurdity of the Latin translation, which the publisher now admits by providing a brand new translation, though I will not take time to discuss it here. I note only that the publisher translates the word HANDBONAN as surrender [460] and on p. 186 [2502] as a dangerous hand (manu periculosa), which is evidently the same word as HAND BANANAN on p. 101 [1330], where the publisher translates it as killing (HAANDBANE), and that it cannot be translated otherwise in any of the other places. I am in no way interested in invent-ing a new name, but when it is written that Ecgpēow was HEAPOLĀFE TO HANDBONAN [460], then Grammar forces me to take Heapoläf to be a name.

Concerning the 8th and 9th Songs, whose obscurity I myself admit, I prefer to remain entirely silent until I have more information, but since the publisher with so grammatical a gesture asks me where the nominative for RÆMIs (p. 41 [519]) could come from if it cannot be HOLM, I will

19 In the manuscript and in Thorkelin's text the lines appear as "he XXXtiges / Manna mægen cræft / On his mund gripe," which Thorkelin translated as "Trecentorum / Virorum robur / Suo sub imperio" [the strength of three-hundred men under his [Beowulf's] command] (1815a, 31). 
certainly ask in return why RÆMIS should have a nominative and cannot like many words be content to stand with a follower in the objective case, as HEAPO is here, and furthermore, where might one get a subject for the verb ÆTBÆR when one tears HOLM out of its arms?

About the Volsung ${ }^{20}$ I cannot say now more than I have already said, and about the word stapole [926] I can only remark that in Somner's Dictionary STAPUL is translated as foundation and STEOPL as tower. I do not know why anyone would choose the unreasonable option every time.

| Col. 1141 Concerning BRand healfodnes (p. 78 [1020]), I will say only that if it is not understood that Hrōðgār is present in the clause contrary to the skald's normal use, then the subject for the verb is FORGंEOF "gave." And also that the sword is explicitly mentioned among the gifts. ${ }^{21}$

The publisher pokes such fun at my words (in Skilderiet No. 64) that however confusing I find the 16th and 17th Songs [1063-1159], I venture to maintain that a Hengest, with his Frisians, accompanied the Dane's army and is presented as its actual chieftain. ${ }^{22}$ His contention is foolish, because the Hengest who visited the Frisians must be his fatherland's enemy and traitor, and he cannot therefore be visiting friends, yet on p. 86 [1125-27] it is clearly stated that they went to Frisia to visit friends, and to see their homeland NESIUN FREONDUM, GESEON HAMAS [visit friends, see home]. ${ }^{23}$ I have a more important objection to the claim that Hengest

20 The reference is to lines 874-97 where Beowulf is compared to Sigemund the Volsung who is called a dragon-slayer. The story differs from the account in the Old Norse Volsungassaga and the Middle High German Nibelungenlied, where the dragon-slaying is attributed to Sigemund's son Sigefried. Grundtvig mentions Sigefried again later in the essay at column 1142.

21 The passage in Beowulf: "Forġeaf pā Bēowulfe brand Healfdenes, / segenen gyldenne sigores tō lēane, / hroden hildecumbor, helm ond byrnan” (1020-22) [He gave to Beowulf the blade of Healfdene, / a gold war-standard as a reward for victory, / the bright banner, a helm and byrnie" (Liuzza 2013, 80). The passage is often emended to mean "the son of Healfdene gave to Beowulf . .."

22 The passage in question concerns what is called the "Finn Episode." The story describes a surprise attack by the Frisians on the Danes and a failed effort to make peace between the two tribes. Finn is the chieftain of the Frisians and Hengest, the chieftain of the Danes. The episode is explained in Fulk (2009, 273-79).

23 The complete line is "Ǵewiton him ðā wig̉end wica neosian / frēondum befeallen, Frȳsland gesēon, / hāmas ond hēaburh" [the warriors left to seek their native lands, / bereft of friends, to behold Frisia, their homes and high fortresses]. 
could be a general term for a "sea-king," ${ }^{24}$ and so I have not mentioned the word among the obvious male names which are thus transformed. However, we are aware that Hengest is undeniably a male name and that in the entire passage on the attack no chieftain is mentioned for the Danish army except Hengest. Since we know of absolutely no examples of this name being used as an appellative, since the time and place can as far as we know allow us to regard this Hengest to be the person of that name, and finally since the grammar in several places does not allow us to take the word as an appellative, then I think I must be right. I shall put off taking this further and only note that when the publisher says WIG HENĠESTE is a sea battle, FIN HENGESTE the sea warrior Fin, and BURH HENĠEST a sea fortress, then Grammar answers short and sweet: HENĠESTE is a clear dative that allows each to stand for itself and dedicate itself only to what is handed to it and is done to it. Something noteworthy in various respects which, to my eyes, were sufficient to demonstrate that it is both about $a$ Hengest and about the well-known Hengest, I have stumbled upon - by chance: but I am nevertheless confident of delighting some people with the information. In Hickes' Thesaurus LINGV. SEPTENTRIONAL. THESAUR. T. I. p. 192 a fragment has been found which is declared to be the only remnant of an old Anglo-Saxon poem. ${ }^{25}$ To conclude from the fragment, it must have been an exceedingly poetic and deeply | Col. 1142 delightful song where a "Skjold Skefte" is introduced, speaking and rousing all his departed heroes, while birds sing and the moon shines in the sky. Then a gold-adorned host of heroes arose, including Sigefred (without doubt Sigurd Fafnisbane, whom the Germans call Sigfred), Ordlaf and Gudlaf and Hengest himself. When we then find in Bjovulfs Drape a Hengest in the Skjolding's service beside a Gudlaf and Oslaf on p. 88 [1148], then we can be in no doubt whatsoever that he is one and the same man, and that an Anglo-Saxon skald is talking about the celebrated Hengest when he says the word Hengest itself. Surely no more proof is needed. If more of the poem could be found, it would undoubtedly solve many a passage not only in Bjovulfs Drape, but also in all of the Anglo-Saxons' ancient poems. Indeed this possibility must be allowed in relation first to Bjovulfs Drape,

24 Though the term "Viking" is anachronistic, it might be an alternate translation of the sentiment packaged in Grundtvig's word "Søkonge."

25 Hickes (1703-5, I. 192-93) provides an edition based on the lost manuscript. 
then to the Englishmen's attitude towards their literary treasures, and finally to the place where the fragment was found (in a homily collection). I cannot therefore regret that on such grounds I argue that the Hengest who is mentioned is undoubtedly a Danish chieftain, unless - and it will be his task to do this - the publisher can prove that I am disseminating foolish ideas.

On the obscure passage in the poem about the Brōsinga-Mene on p. 92 [1199, 1215-1216], I shall engage no further than to repeat that the queen gave Beowulf not it but the necklace, about which the skald clearly says that compared to the Bronsinga-Men a costlier treasure he has not heard spoken of, that Hygelāc had $i t$, and that it is certain that he is called "Sverting's kinsman" in that he is referred to as HIGELAC GEATA NEFA SVERTinges [Hyggelāc the Ġeat, nephew of Sverting, 1201-1202]. It is equally certain that NEFA NEPOS is a clear nominative, and whoever does not know this can see for himself in the poem and in Somner's Dictionary.

In the introduction to the 24th Song [1651-1739] I have said that Beowulf did not give Hrōðgār a giant sword, for it had melted in the hot troll's blood, leaving only the remaining hilt bearing strange runes. The publisher asks if "people" do not know that HILt in Anglo-Saxon and HIALTI in the Edda are terms referring to the entire sword. To this "a person" ${ }^{26}$ answers that he will not quarrel, but that the publisher should see that on p. 122 [1608] we are told about a giant sword, and how strange it was that it completely melted (GEMEALT) just as ice does when it dissolves, which the publisher has even translated as |Col. 1143 Erat Mirum QVOD totus liqvefactus fuerit, glaciei simillimus [It was a miracle that the entire sword became liquefied like ice]. It is said in both the preceding and the following lines that the troll blood caused this and that only the hilt remained, and when Beowulf later on p. 126 [1658-70] talks about this HILT and how on p. 127 [1677-98], when it is handed to Hrōðgār, its runes were spared, then we have reasonable grounds for the HILT to mean here only the hilt and not the usual use of the word. What I do not know, and Somner is silent about, is when it should be used for the entire sword. The objection that such an important legend as the one mentioned could not fit into the space on the hilt is neither the publisher's nor my decision, but the old skald's to defend; for his sake I will therefore recall that when he

26 i.e. Grundtvig himself. 
first conferred on Beowulf the strength of thirty men and expressly stated (p. 118 [1559-61]) that the giant-sword was of course too heavy for any other man than Beowulf, then he can demand that we should measure the sword by Beowulf and the hilt itself by the sword, which, as is fairly obvious, allows space for many words to appear on the hilt.

He has also considered me wrong to take HEREMōD in the 24th Song to be a male name, but the publisher cannot deny that it is indeed an ancient, well-known name, as he himself admits in the 14th Song, where the hero Heremōd is spoken of. Nor can he deny that in the 24th Song a hero again is referred to who is given no other name than HEREMōD on p. 129 [1709], so I can spare myself the trouble of more proof.

With a pathos that has seldom seemed more inappropriate, the publisher complains that I attribute to him the accusation of bloodlust that his Latin translation puts on Hæreð's daughter, Hygelāc's queen, but what else can I say when it is not found in the text? There we read, as I said, some obscure words in the story which I do not understand and which necessarily prevent me from avoiding even the least mistake in translating it. But that is not required here, for just as it is clear that the skald could say even about the most vicious of women, that no one dared approach the animal except its lady, i.e. its owner NÆNIG PÆT DORSTE [no one dared that] etc, (p. 145 [1933]), so is this crystal clear proof against any claim of her "matchless cruelty" towards the king's friends. ${ }^{27}$ Indeed, on her homecoming (p. 149 [1981-1983]) she poured mead in the hall for the returned Beowulf and displayed friendship to all of the king's men! | Col. 1144 To invent another "Hæreð's daughter" only so that the first can continue to be a monster, is an excursion that I, at least, do not see as being to my advantage to pursue; nor do I see it as futile to repeat such an obvious thing, and to note the interesting point that Saxo also speaks of a Swedish "King Hæreð's daughter” whose bower was guarded by monsters (Edit. Steph.

27 Grundtvig shows awareness but misunderstanding of the digression in Beowulf following mention of the character of Queen Hygd. At line 1931, the digression begins with the word "Mōdprȳðo," which has been translated as a name and as the phrase, "mod Prȳðo" (Thyrth's pride, as in Liuzza 2013, 106). Рrȳðo or Mōdprȳðo was a haughty queen who would have men who looked at her killed. But she is eventually taught to be gentle and courteous by her husband, "the kinsman of Hemming" Offa. Missing the significance of the word "Mōdprȳðo," Grundtvig seems to understand that the passage relates to Hygd's past. 
169), for I cannot make the stories tally even though the similarities are nevertheless strange. ${ }^{28}$

The publisher claims that it contradicts the nature of the language to translate suna Frodan as to Frode's son, but if it is true as Hickes says (T. P. 11) that SUNU, son, has in the dative both SUNU and SUNA, then the preceding and corresponding GLADUM is undoubtedly dative, as can be seen at the close of the example in Hickes on p. 16. Finally if FrOdan is genitive, as the example of VITEGA, VITEGAN seems to teach, then I would rather say that the disputed word could not possibly endure a translation other than the one I have given. I shall not engage further in the confusing passage about this same Frode's son starting on p. 132 [2020-2069]. ${ }^{29}$

To return to the utopian Hrēðel and his non-existent sons about whom the publisher is pleased to express himself would be to press the readers' patience too hard, so having provided all the evidence against all the reproaches the publisher has made, I confidently leave judgement to scholars here and everywhere else.

I will only add two more remarks before I come to a conclusion. The first is that no one should think that I imagine myself to be more than what I am, a poor beginner in the Anglo-Saxon language, merely because with Grammar and Dictionary I have successfully led the field against a man who lays claim to twenty-five years of study. Whatever the value of such study, I have here only disarmed it with the innocent little trick of staying silent, or expressing myself carefully where I did not have the correct information, and continually asking Hickes and Somner what they thought about my judgments before I uttered them. Had the publisher

28 The reference is to Stephanius Stephanus Johannis' 1645 edition of Saxo Grammaticus' Gesta Danorum. The story in question appears in book IX. It is about the daughter of the Swedish King Hereoth, Thora, who raises snakes that grow into monsters. Hereoth offers a reward to anyone who can kill them, and Regner Lothbrog accepts the challenge. Grundtvig combines this the story with another immediately preceding it about Lathgertha. In it, Lathgertha has a bear and a hound protect her room from "the enthusiasm of [Regnar's] desires." These episodes are translated in Davidson (1981, 280-81).

29 The passage, often known as the "Ingeld Episode," closely resembles the story of Ingeld, Frotho IV's son, as told by Saxo Grammaticus in Gesta Danorum (Book VI). For a translation of the account, see Davidson (1980, 185-95). 
used the same trick, all of this dispute and a large portion of my toil would have been superfluous, and I would gladly have desired all of this.

The second remark is a little selfish, but surely a valid desire: namely, that certain people | Col. 1145 would once and for all let go of the strange idea that I hate thoroughness, because in my innermost heart I hate the sham scholar and all unjustified evidence. Nor will I allow myself to be tyrannized by an untamed imagination, for though I can in no way serve the publisher or anyone by either translating Bjovulfs Drape or doing anything anywhere without my imagination, I still think that my eager use of Grammar and Dictionary should acquit me of the accusation that I cannot or will not control my little imagination with a grain of Reason.

N.F.S. Grundtvig.

\section{Bibliography}

Works by Grundtvig

- (1815a), "Et Par Ord om det nys udkomne angelsaxiske Digt", Nyeste Skilderie af Kjøbenhavn 60, cols 945-952; 63, cols 998-1002; 64, cols 1009-1015; 65, cols 1025-1030; 66, cols 1045-1047.

- (1815b), "Nok et Par Ord om Bjovulfs Drape", Nyeste Skilderie af Kjøbenhavn 70, cols 1105-1109; 71, cols 1121-1125; 72, cols 1139-1144.

- (1924-1926), Breve fra og til N.F.S. Grundtvig, ed. Georg Christensen \& Stener Grundtvig, volumes 1-2, Copenhagen, Gyldendalske Boghandel Nordisk Forlag.

\section{Works by Other Authors}

Anon (1815), "[Etatsraad Thorkelin seer gjerne. . .]”, Nyeste Skilderie af Kjøbenhavn 75, cols 1185-1186.

Bjork, Robert E. (1996), “Grímur Jónson Thorkelin's Preface to the First Edition of Beowulf, Scandinavian Studies 68, 291-320.

Bradley, S.A.J. (2000), “Det er hvad jeg kalder at oversætte Digte: Grundtvig as translator", Grundtvig-Studier 2000, 36-59. 
Busbee, Mark Bradshaw (trans) (2015), "A Few Words about the Recently Published Anglo-Saxon Poem, the First Edition of Beowulf", Grundtvig-Studier 2015, 7-36.

Cooley, Franklin D. (1940), "Early Danish Criticism of Beowulf", English Literary History 7.1, 45-67.

Davidson, Hilda Ellis, and Peter Fisher (1980), Saxo Grammaticus. The History of the Danes. Book I-IX, vol. II Commentary, Suffolk and New Jersey, D.S. Brewer \& Rowman and Littlefield.

Fulk, R. D., Robert E. Bjork, and John D. Niles (eds.) (2008), Klaeber's Beowulf and the Fight at Finnsburg, $4^{\text {th }}$ ed. (1922), Toronto, Buffalo, and London, University of Toronto Press.

Haarder, Andreas (1988), “The Seven Beowulf Reviewers: Latest or Last Identifications", English Studies 69, 289-92.

Hall, J.R. (1996), "The First Two Editions of Beowulf: Thorkelin's (1815) and Kemble's (1833)", in The Editing of Old English: Papers from the 1990 Manchester Conference, edited by D.G. Scragg and Paul E. Szarmach, Cambridge, Cambridge University Press, 239-250.

Hickes, George, Humphrey Wanley and Andrew Fountaine (1703-05), Linguarum veterum septentrionalium thesaurus grammatico-criticus et archeologicus, Oxford, E Theatro Sheldoniano.

Liuzza, Roy (trans) (2013), Beowulf, $2^{\text {nd }}$ edition, Toronto, Broadview.

[Müller, Peter Erasmus] (1815a), "[Anmeldelse af De Danorum Rebus Gestis]", Dansk Litteratur-Tidende 26, 401-16; 27, 417-32; 28, 432-46; 29, 461-62.

Pontoppidan, Børge (1815), “Til Herr Etatsraad Thorkelin og hans Ordfører i Skilderiet No. 75 d.A.”, Nyeste Skilderie af Kjøbenhavn 85, cols 1345-1348.

Shippey, Thomas, and Andreas Haarder, (ed and trans) (1998), Beowulf: The Critical Heritage, London and New York, Routledge.

Somner, William (1659), Dictionarium Saxonico-Latino-Anglicum,Oxford.

Stephanius, Stephanus Johannis (1645), Saxonis Grammatici Historia Danice Libri XVI, Soræ, Joachimi Moltkenii.

Thorkelin, Grimur Jonsson (1815a), De Danorum rebus gestis secul. III \&IV: Poema Danicum dialect Anglosaxonica: ex Bibliotheca Cottoniana Musaei Britannici / edidit versione lat. Et indicibus auxit Grim. Jonson Thorkelin, Copenhagen, Typis Th. E. Rangel.

- (1815b), "Svar til: 'Et Par Ord om det nys udkomne angelsaxiske Digt'”, Nyeste Skilderie af Kjøbenhavn 67, cols 1057-61; 68, cols 1073-80. 


\section{Endnotes}

i The article appeared in three installments: number 70, on Saturday, 2 September 1815; the second, no. 71, on Tuesday, 5 September, and the third, no. 72, on Saturday, 9 September 1815.

ii Shippey and Haarder $(1998,11-18)$ provide an overview of the debate between the three men during the spring, summer and early fall of 1815 . G.J. Thorkelin (1752-1829) was a venerated scholar, who held positions as Privy Archivist and Counsellor of State. His edition appeared in early May. See Bjork (1996), Cooley (1940), and Hall (1996) for discussions of the work. Haarder $(1988,289)$ identified the reviewer as Peter Erasmus Müller (17761834), who was a doctor of theology, priest, scholar of early Scandinavian literature and, at the time, the editor of Dansk Litteratur-Tidende. Müller's review of Thorkelin's edition appeared in numbers 26 and 27 of the journal.

iii The article was published in five installments: number 60, on 29 July; no. 63, 8 Aug.; no. 64, 12 Aug.; no. 65, 15 Aug.; no. 66, 19 Aug.). See Busbee (2015, 7-36) for an annotated translation of the article.

iv Thorkelin's answer appeared in numbers 67 and 68 of Nyeste Skilderie. Most of Grundtvig's points in "Nok Et Par" are in response to this two-part article. See Shippey and Haarder $(1998,97-99)$ for a translation of portions of this article.

v See Breve I, 372-3. Grundtvig apologized for any severe expressions he might have used, but he did not retract his judgment of Thorkelin's book. Instead, he asked for permission to print a notice which would settle the quarrel and again indicated his intention to translate the poem.

vi George Hickes (1642-1715) published Linguarum veterum septentrionalium thesaurus grammatico-criticus et archeologicus jointly with Humphrey Wanley between 1703-05. The second part of the volume, by Wanley, contains a brief description and transcription of the first 19 lines of Beowulf. Dictonarium Dictionarium Saxonico-Latino-Anglicum was the masterwork of William Somner (1598-1669). The first dictionary of Old English, it became a standard work for teaching at Oxford University.

vii Bülow met with Grundtvig on 9 September 1815. In a follow-up letter, he wrote, "My wish is [...] that your Reverence will translate and publish it, not only poetically, but also literally. When you complete it, I will pay you eight hundred rundles total in order for it to be published. I am well aware of your ability to write poetry and prose, but I expect that your approach will silence this creative flair" (Breve I, 134).

viii Pontopiddan's remarks should be understood against tensions between him and Grundtvig. In the final installment of "Et Par Ord," Grundtvig had complained that Pontoppidan had allowed him to "be crudely vilified and lied about in his journal," and he had written, "I have never been able to count it to his credit to be the publisher of so pitiable a periodical" (1815a, col 
1047; Busbee 2015, 33). Even so, in the piece Pontoppidan graciously rises above past personal grievances to ask, "Who among our scholars can write ... a single page with the same originality, abundance of strength and beauty as Grundtvig" (1815, col 1348). He concludes with a call to Grundtvig to continue his work for the sake of the fatherland and for the sake of religion and truth. 